\title{
"Christ is the Mountain"
}

Some observations on the religious function of symbols in the encounter of Christianity and other religions

\author{
BY CARL HALLENCREUTZ
}

In this paper I will focus on the religious function of symbols in the encounter and interaction of Christianity and other religions. Like Livingstone once, I venture to "draw your attention to Africa". I will illustrate the problem with some observations on the religious function of the symbol of the Holy Mountain in different African contexts. These contexts are a) traditional Kikuyu religion, b) a Christian hymn from Northern Tanzania, and c) the New Year's Fiest of the independent Nazaretha Church among Zulu in South Africa.

\section{Symbols of power or agents of change?}

When we raise the question of the role and function of symbols in the encounter of Christianity and other religions, it may at first seem rewarding to speak of drastic confrontations between Western missions and indigenous religious structures. We can, of course, advance a number of examples of such confrontations from different periods of history. However, at a more detailed study of the history of Christian expansion the problem proves to be more qualified and involved than we first imagined.

Assessing the specific religious function of symbols in such local encounters of Christianity and other religions which took the form of drastic confrontations, I suggest that the predominant role of symbols is to integrate and enforce religious and social structures, which are seen to be mutually exclusive. In the confrontation of religions such symbols became expressions of religious and social power within the opposing structures. S. Axelson illustrates this particular problem in his study of tense relationship of Kikongo banganga and Western missionaries in Lower Congo from the late 15 th century onwards ${ }^{1}$.

However, this is only one aspect of the religious function of symbols in the encounter and interaction of Christianity and other religions. This encounter takes different forms and moves at different levels. Often it becomes personal and internalized among those, who within the framework of their inherited religious tradition get affected by new religious influences and let their inherited religious practises and worldview as well as their

\footnotetext{
${ }^{1}$ Cf. Axelson $15 \mathrm{ff}$.
} 
ethnic loyalties be reorientated by the new religion ${ }^{2}$. As is increasingly made evident in studies in local Church History in Africa, Asia and LatinAmerica religious symbols play a significant role as agents of change in such processes ${ }^{3}$. Further investigations in related problems may be a relevant contribution of Studies in Mission to on-going interdisciplinary search for the religious function of symbols.

\section{Mount Kenya-God andlor abode of God}

Let us first turn our attention to the role of the Holy Mountain in traditional Kikuyu religion!

Today, when Jomo Kenyatta is mourned as a national hero of independent Kenya it is interesting to recall his significant contribution from the 1930 s to East African Anthropology, which he programatically called $\mathrm{Fac}$ ing Mount Kenya ${ }^{4}$. In this study Kenyatta scholarly expounded the social, cultural and religious tradition of his own Kikuyu people. He also gave a profound contribution to the emerging Kenyan nationalism ${ }^{5}$.

Discussing Kikuyu religion Kenyatta illustrates the role of the Holy Mountain. According to Kenyatta "religion is a dramatisation of belief and belief is a matter of social experience of the things that are most significant to human life" of all things animate"7, Kenyatta emphasises the symbolically involved relationship of Kere-Ngai (or Kiri-Nyaga ${ }^{8}$ ) which means the mountain of brightness and is the Kikuyu name for Mount Kenya and Mwene-Ngai (or Mwene-Nyaga) which means the possessor of brightness and is the most often used Kikuyu name for divinity or the Supreme Being in ritual and/or liturgical contexts ${ }^{9}$.

$\mathrm{Ngai}$ is the creator and giver of all things. He is not visible to mortal eyes but manifests himself in natural phenomena such as the sun, the moon, the rainbow and not least in thunder ${ }^{10} . N g a i$ is a distant God, though in times of crisis the Kikuyu calls upon Ngai, as communication with $\mathrm{Ngai}$ is established within the family at significant events in the life of an individual, such as birth, initiation, marriage and death ${ }^{11}$.

Ngai lives in the sky yet Kere-Ngai is believed to be his official resting place. However, apart from Mount Kenya other mountains, such as Kea Njahe (the mountain of the Big Rain=Donyo Sabuk), Kea Mbiroiro (the mountain of the Clear Sky=Ngong), and (Kea-Nyandarwa=Kinan-

\footnotetext{
2 The development of Mvemba Nzinga is one example; cf. ib., $54 \mathrm{ff}$.; $65 \mathrm{ff}$.

${ }^{3}$ Cf. KA 1978, which contains papers on Church and Colonialism in different regions read at CIHEC Conference in Uppsala, August 1977.

${ }^{4}$ Cf. Kenyatta, 1968, 34, on conditions when Kenyatta wrote this study.
}

${ }^{5}$ Cf. Kenyatta 1961, XVII ff.

${ }^{6} \mathrm{Ib} ., 316$.

${ }^{7} \mathrm{Ib}$.

${ }^{8}$ Cf. Kibicho 1978, $371 \mathrm{f}$.

${ }^{9}$ Cf. Kenyatta 1961, 234; Leakey 1077.

${ }^{10} \mathrm{Cf}$. ib. $234 \mathrm{ff}$.

${ }_{11}$ Cf. ib., 243-252. Cf. Leakey 1078 ff.; Mbiti $237 \mathrm{ff}$. 
gop) are seen as minor abodes of $\mathrm{Ngai}^{12}$. Big trees symbolise these holy mountains. Under such trees the traditional Kikuyu worships and makes sacrifices to Mwene-Ngai. Offering his sacrifice the Kikuyu turns towards Kere-Ngai and raises his hands to the holy dwelling place of $N g a i^{13}$.

A younger compatriot of Kenyatta, S. Kibicho, presses this analysis of Kikuyu theology further. He analyses different names of the godhead and draws attention also to Githuri (=the Great Elder) as the name of him, who lives on Kere-Nyaga and makes "mountains tremble and rivers flood" and to whom prayers are adressed ${ }^{14}$. He also specifies the different activities of $N g a i$ and emphasises particularly that according to Kikuyu tradition Ngai is God for all men though the worship of him is conditioned by social frames of reference, family, clan, tribe etc ${ }^{15}$. According to Kibicho this is a significant factor in the continuity of the concept of God in Christian Churches in today's Kenya, in spite of drastic confrontations in the past between Kikuyu religion and Western missions ${ }^{16}$.

Kibicho also ventures an interpretation of the religious function of the Holy Mountain as a symbol in traditional Kikuyu religion and world view. He draws attention to the relationship of the name of God and the name of the Holy Mountain, but following Kenyatta he does not suggest a complete identification of the symbol with what it symbolises as characteristic of the Kikuyu understanding of the relationship of God to Mount Kenya. Instead he distinguishes between two aspects of the Holy Mountain as a religious symbol. On the one hand Mount Kenya-more, perhaps, than other mountains-was a representative symbol. It witnessed to the presence and the power of the high God. On the other hand Mount Kenya was also an effective symbol. It was "imbued with the very power and presence of God". As such an effective symbol it could properly be addressed to in worship as an active manifestation of divinity ${ }^{17}$.

The holy mountain, thus, plays a significant role as a symbol in traditional Kikuyu religion. It continues to do so also among Christian Kikuyu although Kiicho admits that the predominant missionary attitude did not ask for points of contracts for the Christian Message in traditional Kikuyu religion but assumed a relationship of radical discontinuity. To the Kikuyu, however, the concept of Ngai as God for all men provided a religious framework for appropriating the new religious and social influences, in the encounter with Christianity and education (githoma) and social progress became new values in a period of drastic disintegration of traditional structures after the British colonial expansion. Conversion to Christianity

${ }^{12}$ Cf. Kenyatta 1961, 236.

${ }^{13}$ Cf. ib.; Leakey $1078 \mathrm{ff}$.

${ }^{14}$ Cf. Kibicho 1978, 372; Kenyatta 1961, $246 \mathrm{f}$. is Cf. ib.; Kenyatta 1961, 234.

${ }^{16}$ Cf. ib., $380 \mathrm{ff}$.

17 Cf. Kibicho 1965, 2 ff. 
actually, was called Guthoma, which literally means "to read" or "to become a literate" 18 .

What is the religious function of the holy mountain to the Christian Kikuyu and to Christians in other parts of Africa? In order to illustrate this problem II turn to a Christian hymn to the Holy Mountain from Northern Tanzania and the New Year's Fiest of the Zulu Nazaretha Church.

\section{The Holy Mountain-a symbol for Christ}

The Holy Mountain, thus continues to be a living symbol for many Christians in Africa. This is a more involved fact than a mere illustration of the easy identification which African Christians can make of his own situation with Old Testament realities. As the Psalmist of old, the African Christian, too, can lift his eyes to the hills and ask "from whence does my help come" (Ps. 121,1). Nor does the religious functions of the traditional mountain symbolism in the Christian context reflect, only a local appropriation of Evangelical references, to the "rock of ages cleft for thee".

In the encounter of Christianity and traditional African religions the religious function of the mountain symbol actually is twofold. In the first place it becomes a carrier of a new religious message and gets influenced by what this message conveys. At the same time it serves as an indigenous means whereby this message can be appropriated in its religious sense. There is then a dialectic of continuity and discontinuity in the religious function of the symbol of the holy mountain-and I suggest in other symbols, too-in the encounter. The symbol takes on wider both religious and social references in the process ${ }^{19}$. This is illustrated very well in a Chagga-hymn to the holy mountain and to $\mathrm{Christ}^{20}$, which however, does not seem to be very widely used and is not included in the Kiswahili Hymnal the Evangelical Lutheran Church of Tanzania (ELCT).

Among the Chagga on the slopes of Kilimanjaro in Northern Tanzania there has developed a local Christian culture, which has become a significant part of ELCT. With its impressive stature and its glacier, Mount Kilimanjaro, of course, is suggestive as a symbol to both Christian and pre-Christian Chagga ${ }^{21}$. As such it is praised also, in the Christian Chagga hymn, to which we have referred. It introduces its theme in unequivocal terms:
There raises a chieftain
bright and beautiful, high above all mountains.
It is Kilimanjaro, which everybody can see.

\footnotetext{
18 Kibicho 1978, $372 \mathrm{ff}$, $383 \mathrm{f}$. Cf. further Macpherson $93 \mathrm{ff}$.

${ }^{19}$ Cf. Shorter $66 \mathrm{ff}$.
}

20 The hymn is published in German translation in Rosenkrantz $124 \mathrm{f}$.

21 Cf. Dundas $32 \mathrm{ff}$. 
Mount Kilimanjaro is believed to have been installed by God. As such it is a holy mountain and the hymn expresses the religious function of this symbol in a way which corresponds very well to characteristic features of traditional Kikuyu religion. It, thus, affirms:

The bright appearance of Kilimanjaro

became a sign to the Chagga

from God, the Highest, who sheds light upon us

as a bright light without an equal.

The glorious glacier on Kilimanjaro's forehead testifies that God is with us.

If we focus more especially on the way in which the religious function of the symbol of the holy mountain is understood here we can note-in Kibicho's terminology - that Mount Kilimanjaro is primarily seen as a representative symbol, which witnesses to the presence and power of the high God. It does not say explicitly that Kilimanjaro is the abode of God "imbued with the very power and presence of God".

However, the hymn does not end here. It moves a step further and developes the traditional mountain-symbol by relating it to Christ. Without in any way denying the validity of what the traditional symbol signifies and communicates, it states in terms of a witness to Christ:

It is Jesus, your son,

Who makes visible what is prepared for our salvation.

He is the Mountain full of eternal brightness.

He gives us courage

to fulfill our duties

under your guiding hands.

O Jesus, your countenance, which shows forth God's glory, excells the light of Kilimanjaro.

In your name everything shall bow down.

It is worth noting here, that Jesus is addressed to as the son of the same divinity, to whom Mount Kilimanjaro testifies! The hymn, thus, explicitly affirms the continuity. of the traditional references of the symbol of the mountain with what is contained in the revelation of Christ, the Holy Mountain. At the same time it implies that the traditional references are qualified and reorientated when they are related to the divine mysteries which Christ discloses. As a religious symbol Mount Kilimanjaro becomes 
secondary to Christ, in the same way as the holy trees in traditional Kikuyu worship is secondary to Kere-Ngai.

This development of the symbol of the holy mountain might mean that in the encounter of Christianity and traditional Chagga religion Mount Kilimanjaro as a Holy Mountain has become obsolete. This is an exclusive interpretation, which emphasises the element of discontinuity in the encounter. I doubt, however, whether that is the necessary interpretation of the hymn. Instead I suggest that the hymn reflects a reorientation and further development of the traditional symbol of the Holy Mountain, when in the encounter it becomes a carrier of the Christian message and gets influenced by what this message contains and refers to. As a representative symbol, thus, the Holy Mountain refers from itself to him who is seen to make manifest divinity in its very essence. As such Christ stands forth as the effective symbol who makes divine presence concrete and is brighter and reaches further than Mount Kilimanjaro and its glacier. This further implies that the social terms of reference of the traditional symbol are widened and that there is involved a critique of social and religious loyalities which are defined primarily in tribalistic terms ${ }^{22}$.

The Christian Chagga-hymn to the holy mountain, thus, illustrates the religious function of the symbol within a qualified, continuous relationship of Christianity to traditional African religion. However, this is not the only way traditional mountain symbolism functions in Christian spirituality in Africa. There are also more radical, continuous relationships particularly among so called independent Church movements.

Both Kenyatta and Kibicho illustrate that this holds ture also for Kenya. Kenyatta, thus, comments on the worship of Mwene-Ngai facing Kiri-Ngai among the so called Watu wa Nugu or People of God, a breakaway group from the emerging Presbyterian Church of East Africa ${ }^{23}$. Kibicho on the other hand refers to the radical continuity with traditional Ngai-worship among Christian Mau Mau freedom fighters. He even quotes one of their hymns:

\author{
Pray earnestly \\ beseech truly, \\ for God is the same \\ one of ancient times ${ }^{24}$.
}

Even so, the problem of independent church movements is particularly challenging in South Africa. As I have already mentioned I will illustrate alternative functions of the symbol of the holy mountain in Christian spirituality in Africa with some reflections on the New Year's Fiest of the Nazaretha Church.

${ }^{22}$ Cf. Kibicho 1978, $366 \mathrm{f}$.

${ }^{23}$ Cf. Kenyatta $1961,273 \mathrm{ff}$.

${ }^{24}$ Kibicho 1978, $381 \mathrm{ff}$. 


\section{The royal mountain and Christ}

At a previous symposion, which dealt with new religious movements, Bengt Sundkler illustrated characteristics of independent church movements among Swazi and Zulu ${ }^{25}$. The Nazaretha Church is one of the more distinct of these movements with charismatic and/or "Zionist" features ${ }^{26}$. It is inspired by a rich heritage from Isaiah Shembe, prophet, church-leader and hymn-writer.

The New Year's Fiest plays a central role in the worship of the Nazaretha church ${ }^{27}$. In an extraordinary $\mathrm{BBC}$ series on different religions it was presented to a greater audience. This Fiest recalls the initiation of the Nazaretha church and it can be compared to an annual covenant service within Methodism.

The New Year's Fiest at Inhlangakozi can be a prolonged and lively festival where singing of Shembe's hymns with their characteristic rythm is an integral element ${ }^{28}$. The climax of the fiest is the procession uphill Inhlangakozi with the sermon of the prophet and the ritual on the peak of the mountain. At a terrass below the peak, the prophet, at present a grand-son of Isaiah Shembe, gives a sermon, which is based on the Bible and functions as an annual confirmation of the $\mathrm{Law}^{29}$.

After the sermon, which can last for more than an hour the prophet invites his people to climbe the peak. There new rituals including dances and a Communion Service take place. There each participant also performs a particular rite: takes a stone, spits on it and throws it on a cairn. No prayers are said, the ritual as such is seen to bring blessing ${ }^{30}$. The holy mountain functions as an effective symbol of divine presence ${ }^{31}$.

In his Hymnal, Isaiah Shembe expresses the significance of the new year ritual on the holy mountain ${ }^{32}$. In one of these hymns Shembe encourages his people:

The enemies of Jehova

rise up against you.

Rise up, rise up

Ye Africans.

Those are given kingly authority upon the mountain.

\footnotetext{
${ }^{25}$ Cf. Sundkler 1975, $215 \mathrm{ff}$.

${ }^{26}$ Sundkler 1976, $161 \mathrm{ff}$., where the Zionist characteristics of the Nazaretha Church is emphasised.

27 Sundkler 1976, $167 \mathrm{ff}$., $178 \mathrm{ff}$., where the New Year's Fiest at Inhlangakozi is studied with reference also to the annual July festival at Ekuphakaweni, where the prophet lives. In this ritual, too, the mountain symbolism is involved.
}

\footnotetext{
28 Cf. ib., $183 \mathrm{ff}$.

${ }^{29} \mathrm{Cf}$. Becken $138 \mathrm{ff}$.

${ }^{30}$ Cf., ib. 148.

${ }^{31}$ Cf. Sundkler 1976, $197 \mathrm{ff}$., where worship at Ekuphakaweni is interpreted in terms of realised eschatology.

32 On the interpretation of Shembe's hymnal, cf. Sundkler 1976, $190 \mathrm{ff}$.
} 
Rise up, rise up

Ye Africans.

They already want to deprive

the eternal kingly authority.

Rise up, rise up

Ye Africans ${ }^{33}$.

Compared with what we have learned, so far, of the ritual function of the holy mountain it is interesting to note that what this symbol communicates is interpreted in terms of $u b u k h o z i$, kingly authority. This should be understood with reference both to the role of divine kingship among Zulu and the relationship of Shembe's family to Zulu royalit ${ }^{34}$.

The holy mountain of the Nazaretha church is, thus, related both to the sanctified royal ancestry of the Zulu nation and to the God of the Bible. Inhlangakozi is both a Mount Zion and a place where Zulu ubukhozi is restored and experienced ${ }^{35}$.

In the religious function of Inhlangakozi as a symbol, thus, we see another example of the characteristic dialectic of continuity and discontinuity in what the symbol referred to in its traditional context and what it represents and communicates in its new christianized framework. It seems, however, as if the continuity here is more radical compared to the Chagga hymn. This hymn represents a more advanced reorientation of the traditional symbol.

\section{Concluding remarks}

These examples of how the symbol of the holy mountain is used in different religious contexts in Africa are, of course, too limited to provide a basis for far-reaching generalizations on how symbols function religiously in the encounter of Christianity and other religions. I dare to suggest, however, that this kind of analysis can be applied also when studying other encounters of religions inside and outside Africa. I furthermore suggest that what I have said of the possibility of the symbol to function both as a carrier of a new religious message and as an indigenous means to appropriate this message locally and give it adequate form in different milieus is relevant not only for the African contexts which I have tried to illustrate.

In one respect this argument should be qualified, however. The symbols, which most likely have the religious functions which I have discussed are those which are of a general nature; light, way, living water, and which some are tempted to speak of as archetypes. Yet the comparison between the Chagga-hymn to the holy mountain and Shembe's interpretation of the

${ }^{33}$ Cf. Oosthuizen $159 \mathrm{f}$.

${ }^{35}$ Cf. Sundkler 1976, 195 f. and $313 \mathrm{ff}$.

34 Cf. Berglund $35 \mathrm{f}$, $198 \mathrm{f}$.; Sundkler 1976, 168. 
blessing of the New Year's Fiest on Inhlangakozi indicates, that in the encounter of Christianity and other religions it is not only the symbols as such which produce the local appropriation of the new religious message and give it adequate localized form. Not even in the encounter of Christianity and other religions the symbols function religiously without human beings as actors in the historical process.

\section{Bibliography}

Axelson, S., 1970, Culture confrontation in Lower Congo. Diss. Uppsala. Studia Missionalia Upsaliensia 13. Uppsala.

Becken, H.-J., 1967, On the holy mountain, a visit to the New Year's Festival of the Nazaretha Church on Mount Nhlangakozi Journal of African religion 1.

Berglund, A., 1975, Zulu thought-patterns and symbolism. Diss. Cape Town. Studia Missionalia Upsaliensia 22. Uppsala.

Dundas, C., 1968, Kilimanjaro and its people. London.

Kenyatta, J., 1961, Facing Mount Kenya. London.

- 1968, Suffering without bitterness. Nairobi.

Kibicho, S., 1965, Traditional Kikuyu religion, Report from Ecumenical workshop in religious research. (Mimeographed) Nairobi.

- 1978, The Continuity of the African conception of God into and through Christianity: a Kikuyu case-study. Christianity in independent Africa. Ed. E. FasholéLuke, R. Gray a. o. London.

Kyrkohistorisk Årskrift 1977, Utg. I. Montgomery, Uppsala.

Leakey, L., 1977, The Southern Kikuyu before 1903, 1-3. London.

Macpherson, R., 1970, The Presbyterian church in Kenya. Nairobi.

Mbiti, J., 1970, Concepts of God in Africa. London.

Oosthuizen, C., 1967, The Theology of a South African Messiah. Leiden.

Rosenkrantz, G., 1951, Das Lied der Kirche in der Welt. Tübingen.

Shorter, A., 1973, African culture and the Christian church. London.

Sundkler, B., 1975, The New in the New Religious Movements among Zulu and Swazi. Scripta Instituti Donneriani Aboensis 7.

- 1976, Zulu Zion and some Swazi Zionists. Studia Missionalia Upsaliensia 29. Uppsala. 